BUDGETING : Journal of Business, Management and Accounting

Volume 2, Nomor 1, Desember 2020

e-ISSN: 2715-2480

p-ISSN: 2715-1913

DOI : https://doi.org/10.31539/budgeting.v2i1.804

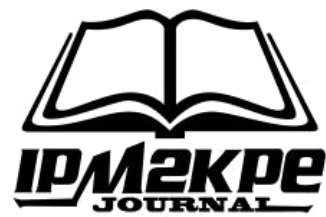

\title{
AKUNTANSI PEMBIAYAAN MUDHARABAH BERDASARKAN PSAK NO. 105
}

\author{
Khoirotul Inzani $^{1}$, Moh.Halim ${ }^{2}$, Elok Fitriya ${ }^{3}$ \\ Universitas Muhammadiyah Jember ${ }^{1,2,3}$ \\ Khoirotuliin@gmail.com ${ }^{1}$
}

\begin{abstract}
ABSTRAK
Tujuan penelitian ini adalah untuk menganalisis akuntansi pembiayaan mudharabah berdasarkan PSAK No. 105 di BMT Manarul Qur'an Lumajang. Metode yang digunakan dalam penelitian ini adalah deskriptif kualitatif dengan menggunakan data primer yaitu wawancara langsung dengan objek. Adapun data sekunder yaitu bukubuku, laporan-laporan yang berkaitan dengan objek penelitian. Metode validitas data menggunakan triangulasi sumber data. Hasil penelitian yang dilakukan menunjukkan bahwa akuntansi pembiayaan mudharabah yang diterapkan oleh BMT Manarul Qur'an Lumajang belum sepenuhnya memenuhi PSAK No. 105. Simpulan, pengakuan laba, pengukuran dan pengungkapan sesuai dengan PSAK No. 105. Adapun pengakuan atas investasi, pengakuan kerugian, pengakuan piutang, pengakuan beban dan penyajian tidak sesuai dengan PSAK No. 105.
\end{abstract}

Kata Kunci: Akuntansi Mudharabah, PSAK No.105

\section{ABSTRACT}

The purpose of this study was to analyze the accounting for mudharabah financing based on PSAK No. 105 in BMT Manarul Qur'an Lumajang. The method used in this research is descriptive qualitative using primary data, namely direct interviews with the object. As for secondary data, namely the books, reports relating to the object of research. The data validity method used triangulation of data sources. The results of the research conducted indicate that the mudharabah financing accounting applied by BMT Manarul Qur'an Lumajang has not fully complied with PSAK No. 105. Conclusion, profit recognition, measurement and disclosure in accordance with PSAK No. 105. As for the recognition of investment, recognition of losses, recognition of receivables, recognition of expenses and presentation are not in accordance with PSAK No. 105.

Keywords: Mudharabah Accounting, PSAK No. 105

\section{PENDAHULUAN}

Lembaga perbankan dan keuangan berbasis syariah di Indonesia berkembang dengan pesat. Bank Muamalat merupakan Bank Syariah pertama di Indonesia yang berdiri pada tahun 1991. Bank Syariah di Indonesia menunjukkan perkembangan yang cukup signifikan setiap tahunnya. Perkembangan pertumbuhan Bank Syariah juga diikuti dengan perkembangan jaringan kantor. Menurut Otoritas Jasa Keuangan (OJK) 
(2018), data statistik Perbankan Syariah pada bulan Oktober 2018, jumlah Bank Umum Syariah (BUS) adalah sebanyak 14 perusahaan, sedangkan jumlah Unit Usaha Syariah (UUS) 20 unit, dan BPRS sebanyak 168 perusahaan dengan total aset BUS dan UUS 454.249. Tidak hanya itu, Institusi Keuangan Non-Bank Syariah (IKNB Syariah) juga mengalami perkembangan yang cukup signifikan untuk setiap tahunnya. Pada bulan Oktober 2018, jumlah perusahaan asuransi syariah berjumlah 13 yaitu lembaga pembiayaan syariah berjumlah tujuh, lembaga jasa keuangan khusus syariah berjumlah tujuh, lembaga keuangan mikro syariah sebanyak 53 dan ditambah satu lembaga dana pensiun dengan total aset keseluruhan 99.715 miliar.

BMT Manarul Qur'an Lumajang merupakan Lembaga Keuangan Syariah yang berdiri dengan usaha untuk mengembangkan perekonomian daerah khususnya dalam pengembangan usaha skala kecil dan mikro. Kegiatan operasional BMT Manarul Qur'an Lumajang pada dasarnya sama dengan yang diterapkan oleh lembaga keuangan mikro lainnya, dengan tidak menerapkan prisip bunga tetapi bagi hasil dan kerugian. Oleh karena itu, akuntansi yang diterapkan seharusnya juga mengikuti sistem akuntansi syariah.

Salah satu produk unggulan pembiayaan BMT Manarul Qur'an Lumajang adalah pembiayaan mudharabah. Secara teknis mudharabah adalah suatu akad perjanjian kerja sama usaha dimana pihak pertama sebagai pemilik dana (shahibul maal) dan pihak kedua bertanggungjawab atas pengelola dana (mudharib) untuk melakukan kegiatan usaha, keuntungan hasil usaha dibagi atas dasar nisbah bagi hasil menurut kesepakatan kedua belah pihak, sedangkan jika terjadi kerugian maka shahibul maal akan kehilangan sebagian imbalan dari hasil kerjanya selama proyek berlangsung (Yaya \& Martawireja, 2012). Hasil Statistik Perbankan Syariah (SPS) yang dipublikasikan oleh OJK menunjukkan tiga akad pembiayaan syariah terlaris tumbuh cemerlang pada September 2018. Dengan kata lain, yang paling dominan adalah akad murabahah dengan nilai pembiayaan bulan September 2018 mencapai 154.845 miliar, jumlah ini meningkat dibandingkan dengan bulan Agustus 2018 yaitu 150.772 miliar, kemudian akad musyarakah dengan pembiayaan pada bulan September 2018 mencapai 121.218 miliar, jumlah ini meningkat dibandingkan dengan bulan Agustus 2018 yaitu 119.598. Terakhir, pembiayaan akad mudharabah pada bulan Septemberr 2018 jumlah 
pembiayaanya 15.673 miliar, jumlah ini meningkat dibandingkan dengan bulan Agustus 2018 yaitu 14.624 miliar.

Tidak hanya itu, hasil Statistik Institusi Keuangan Non-Bank Syariah (IKNB Syariah) menunjukkan akad pembiayaan syariah yang paling dominan adalah akad murabahah dengan nilai pembiayaan bulan September sampai Desember 2018 mencapai 49 miliar, jumlah ini meningkat dibandingkan dengan bulan Mei sampai Agustus 2018 yaitu 30 miliar, kemudian akad musyarakah dengan pembiayaan pada bulan September sampai Desember 2018 mencapai 9 miliar, jumlah ini meningkat dibandingkan dengan bulan Mei sampai Agustus 2018 yaitu 8 miliar. Terakhir, pembiayaan akad mudharabah pada September sampai Desember 2018 jumlah pembiayaanya 6 miliar, jumlah ini meningkat dibandingkan dengan bulan Mei sampai Agustus 2018 yaitu 5 miliar (OJK, 2018).

Rendahnya pembiayaan bagi hasil (mudharabah) pada Perbankan Syariah merupakan suatu fenomena yang terjadi tidak hanya di Perbankan Syariah, melainkan juga terjadi pada Lembaga Keuangan Mikro Syariah yang baru merintis (masih dalam masa transisi) dan yang telah lama berdiri. Penyaluran pembiayaan mudharabah dinilai mudah mengalami atau rentan terhadap penyimpangan, seperti kemungkinan adanya tindak kecurangan dari mudharib yang menyebabkan berkurangnya tingkat pengembalian yang diterima shahibul mal, hal ini merupakan beberapa permasalahan penyaluran pembiayaan mudharabah kepada masyarakat.

BMT Manarul Qur'an Lumajang sebagai Lembaga Keuangan Syariah, memerlukan dasar dalam penyusunan dan penyajian laporan keuangan agar informasi dalam laporan keuangan dapat dipahami, relevan dan dapat dibandingkan serta berguna bagi pemakai laporan keuangan syariah. Hal ini memiliki implikasi yang sangat berpengaruh pada aspek operasional dan produk yang dikembangkan. Pedoman dalam melakukan praktek akuntansi dimana mencakup semua aspek yang berkaitan dengan akuntansi disebut dengan Pernyataan Standar Akuntansi Keuangan (PSAK). Dalam perlakuan akuntansi pembiayaan mudharabah, BMT Manarul Qur'an harus mengikuti ketentuan tentang akuntansi mudharabah yang diatur dalam PSAK No. 105 Tahun 2007 tentang akuntansi mudharabah. Standar ini mengatur pengakuan dan pengukuran transaksi, baik dari sisi pemilik dana maupun dari sisi pengelola dana. 
Hasil penelitian Purwoko \& Setiawan (2016) pengakuan investasi di BMT Amal Muslim Yogyakarta belum sesuai dengan PSAK No. 105, karena pada saat penyerahan dana kepada anggota diakui sebagai pembiayaan mudharabah. Sedangkan menurut PSAK No.105 paragraf 12 dijelaskan pengakuan penyerahan dana mudharabah kepada anggota diakui sebagai investasi mudharabah. Penelitian Darmawan \& Hamid (2018), metode bagi hasil yang digunakan oleh Bank BNI Syariah Kantor Cabang Mikro Kota Parepare belum sesuai dengan PSAK No. 105 karena metode bagi hasil yang digunakan menggunakan metode reveniu sharing yaitu pembagian hasil yang dihitung dari total pendapatan pengelolaan dana tanpa dikurangi dengan biaya-biaya yang dikeluarkan dalam pengelolaan dana tersebut.

Survey pendahuluan pada BMT Manarul Qur'an Lumajang menunjukkan pembiayaan mudharabah pertahunnya mengalami peningkatan sejak berdiri pada tahun 2016. Hal itu dikarenakan anggota atau nasabah yang terdiri dari wali santri di sekitar pondok pesantren yang lebih lekat dengan sistem Islam sehingga menghindari sistem ribawi. Sistem ini tidak memberatkan bagi semua pihak karena menggunakan sistem bagi hasil untuk pembiayaan mudharabah dengan persentase yang disepakati kedua belah pihak di awal akad. Selain itu, pengelola dana mendapatkan pengamanan usaha karena mendapatkan pelatihan dari tim BMT mengenai usaha tersebut. Berdasarkan hasil wawancara dengan bagian keuangan, pada saat pembayaran kas atau nonkas terhadap anggota belum ada kejelasan, dana diakui sebagai pembiayaan atau investasi, dan usaha mudharabah dianggap mulai berjalan sejak dilakukannya akad. Sehingga peneliti bermaksud ingin mengetahui analisis akuntansi pembiayaan mudharabah berdasarkan PSAK No. 105 pada BMT Manarul Qur'an Lumajang supaya dapat menjadi bahan evaluasi terhadap pihak BMT Manarul Qur'an Lumajang.

\section{KAJIAN TEORI}

\section{Pengertian Baitul Maal wat Tamwil (BMT)}

Mawarid (2014) menyatakan BMT merupakan Lembaga Keuangan Mikro yang berlandaskan prinsip syariah. Usaha pokok dari BMT yaitu memberikan pembiayaan dan jasa-jasa dengan tidak menggunakan bunga tetapi menggunakan system bagi hasil dengan berlandaskan pada Al-Qur'an dan Al-Hadits. Lembaga ini didirikan dengan 
tujuan untuk memfasilitasi masyarakat bawah yang tidak terjangkau oleh pelayanan Bank Syariah atau BPR Syariah (Mardani, 2015).

\section{Peran Baitul Maal Wat Tamwil (BMT)}

Mardani (2015) berpendapat bahwa BMT setidaknya mempunyai beberapa peran diantaranya: 1) menjauhkan masyarakat dari praktik ekonomi nonsyariah. Aktif melakukan sosialisasi di tengah masyarakat tentang arti penting sistem ekonomi islami; 2) melakukan pembinaan dan pendanaan usaha kecil. BMT harus bersikap aktif menjalani fungsi sebagai lembaga keuangan mikro; 3) melepaskan ketergantungan pada rentenir; 4) menjaga keadilan ekonomi masyarakat dengan distribusi yang merata.

\section{Prinsip Baitul Maal Wat Tamwil (BMT)}

Mardani (2015) berpendapat prinsip dasar pendirian BMT terdiri dari: 1) keterpadun ( $k a f f a h)$, yaitu nilai-nilai spiritual yang berfungsi dalam mengarahkan dan menggerakkan etika dan moral yang dinamis, proaktif, progresif, adil dan berakhlak mulia; 2) meningkatkan keimanan dan ketakwaan kepada Allah SWT, dengan mengimplementasikan prinsip-prinsip syariah dan muamalah islami dalam kehidupan masyarakat; 3) kekeluargaan; 4) kebersamaan; 5) kemandirian; 6) profesionalisme; 7) konsisten, berkelanjutan tanpa henti dan tanpa putus asa. Setelah mencapai suatu tahap, maju ke tahap berikutnya dan hanya mengharap ridha Allah SWT.

\section{Pengertian Pembiayaan Mudharabah}

Laksmana (2009) menyatakan bahwa pembiayaan merupakan pendanaan yang diberikan suatu pihak kepada pihak lain dengan tujuan untuk mendukung investasi yang akan direncanakan, baik dilakukan sendiri maupun lembaga. Mudharabah merupakan akad bagi hasil ketika pihak pemodal (shahibul maal) menyediakan modal (100\%) kepada pengelola dana (mudharib) untuk melakukan aktivitas produktif, dan keuntungan yang dihasilkan dibagi atas dasar kesepakatan yang ditentukan sebelumnya dalam akad (Ascarya, 2007). 


\section{Landasan Hukum Pembiayaan Mudharabah}

\section{Al-Qur'an}

Firman Allah QS. Al-Ma'idah [5]:1:

"Hai orang-orang yang beriman, penuhilah aqad-aqad itu. Dihalalkan bagimu binatang ternak, kecuali yang akan dibacakan kepadamu (yang demikian itu) dengan tidak menghalalkan berburu ketika kamu sedang mengerjakan haji. Sesungguhnya Allah menetapkan hukum-hukum menurut yang dikehendaki-Nya."

\section{Al-Hadist}

Hadist Nabi Riwayat Ibnu Majah, "Ada tiga hal yang mengandung berkah yaitu jual beli tidak secara tunai, muqaradhah (mudharabah) dan mencampur gandum dengan jewawut untuk keperluan rumah tangga, bukan untuk dijual”.

\section{Ijma'}

Diriwayatkan, sejumlah sahabat menyerahkan (kepada orang mudharib) harta anak yatim sebagai mudharabah dan tidak ada seorang pun mengingkari mereka. Karenanya, hal itu dipandang sebagai ijma'.

\section{Qiyas}

Transaksi mudharabah diqiyaskan kepada transaksi musaqah.

\section{Jenis-jenis Pembiayaan Mudharabah}

Menurut Fatwa Dewan Syari'ah Nasional (2000) No.07/DSN-MUI/IV/2000 tentang pembiayaan mudharabah. Pembiayaan mudharabah berdasarkan PSAK No. 105 tentang akuntansi mudharabah, diklasifikasikan ke dalam tiga jenis yaitu: 1) mudharabah muthlaqah adalah bentuk kerjasama di mana pemilik dana memberikan kebebasan kepada pengelola dana dalam mengenai tempat, cara, maupun objek investasi atau sektor usaha; 2) mudharabah muqayyadah adalah bentuk kerjasama di mana pemilik dana memberikan batasan kepada pengelola antara lain mengenai tempat, cara, maupun objek investasi atau sektor usaha; 3) mudharabah musytarakah adalah bentuk kerjasama mudharabah di mana pihak pengelola dana menyertakan modal atau dananya dalam kerja sama investasi. 


\section{Rukun Mudharabah}

Yaya \& Martawireja (2012) berpendapat mengenai beberapa rukun yang harus ada dalam akad mudharabah, rukun mudharabah adalah sebagai berikut: 1) transaktor; 2) objek mudharabah; 3) nisbah keuntungan; 4) ijab dan qabul.

\section{METODE PENELITIAN}

Penelitian ini dilaksanakan di BMT Manarul Qur'an yang beralamat di Jalan Soekarno Hatta, Biting Dua, Selokbesuki, Sukodono, Kabupaten Lumajang, Jawa Timur 67352. Penelitian ini merupakan penelitian deskriptif dengan pendekatan kualitatif. Berdasarkan pendekatan ini, peneliti akan mengumpulkan, mempersiapkan serta menganalisis data yang berasal dari wawancara, catatan laporan tahunan, maupun dokumentasi sehingga nantinya dapat memberikan gambaran mengenai penerapan akuntansi pembiayaan mudharabah dari BMT Manarul Qur'an. Jenis data yang digunakan dalam penelitian ini adalah: 1) data primer, data-data tersebut berupa data hasil wawancara dan observasi langsung dengan beberapa pihak BMT Manarul Qur'an untuk mendapatkan informasi yang dibutuhkan; 2) data sekunder, data sekunder yang diperlukan antara lain gambaran umum mengenai BMT Manarul Qur'an, laporan keuangan BMT berupa neraca dan laporan laba rugi, PSAK No. 105 dan beberapa literatur lain yang berhubungan dengan penelitian ini.

Adapun teknik pengumpulan data yang digunakan pada penelitian ini adalah sebagai berikut: 1) wawancara, teknik wawancara dalam penelitian ini adalah teknik wawancara terstruktur yaitu dalam penelitian ini mengajukan pertanyaan yang berkaitan transaksi atas pembiayaan mudharabah kepada bagian keuangan, serta berbagai pihak yang terkait dengan penelitian tersebut; 2) dokumentasi, dokumentasi dalam penelitian ini berasal dari catatan-catatan atau dokumentasi berupa laporan keuangan atas pembiayaan mudharabah serta berbagai dokumen yang relevan dengan penelitian ini.

Tahapan-tahapan dalam penelitian ini adalah: 1) mengumpulkan data-data dan informasi melalui wawancara terkait dengan pembiayaan mudharabah pada BMT Manarul Qur'an Lumajang; 2) mengelompokkan data-data yang diperoleh dan memfokuskan pada perlakuan akuntansi mengenai pengakuan, pengukuran, penyajian, dan pengungkapan pembiayaan mudharabah pada BMT Manarul Qur'an Lumajang; 3) 
menyajikan data dalam bentuk tabel alur perlakuan akuntansi mengenai pengakuan, pengukuran, penyajian, pengungkapan pembiayaan mudharabah pada BMT Manarul Qur'an Lumajang; 4) menganalisis kesesuaian akuntansi pembiayaan mudharabah yang ada pada BMT Manarul Qur'an Lumajang dengan PSAK No.105 tentang pengakuan, pengukuran, penyajian, pengungkapan; 5) setelah mengetahui kesesuaian perlakuan akuntansi mudharabah yang terjadi pada BMT Manarul Qur'an Lumajang dengan PSAK No. 105 sehingga dapat ditarik kesimpulan dari hasil penelitian tersebut.

Untuk menguji apakah penelitian penulis dapat dipercaya kredibilitasnya, maka dilakukan pengujian kredibiltas data atau kepercayaan atas hasil penelitian sesuai dengan teori umum yang digunakan dalam penelitian kualitatif yaitu dengan triangulasi sumber data yaitu dengan cara mengecek data yang telah diperoleh melalui beberapa sumber (Sugiyono, 2005). Peneliti menggunakan wawancara kemudian dicek dengan dokumen yang terkait.

\section{HASIL PENELITIAN}

Perlakuan Akuntansi Mengenai Pengakuan Pembiayaan Mudharabah di BMT Manarul Qur'an Lumajang

Tabel 1.

Pengakuan Investasi

\begin{tabular}{clcc}
\hline Tanggal & \multicolumn{1}{c}{ Jenis Data } & \multicolumn{2}{c}{ Dana } \\
\hline \multirow{2}{*}{$03-06-2018$} & Pembiayaan Mudharabah-Umar & Rp.10.000.000 & \\
\cline { 2 - 3 } & Kas & & Rp.10.000.000 \\
\hline
\end{tabular}

Sumber : BMT Manarul Qur'an Lumajang yang diolah

Dana mudharabah yang disalurkan oleh BMT Manarul Qur'an Lumajang kepada anggota (mudharib) diakui sebagai pembiayaan pada saat pembayaran kas, dan usaha mudharabah berjalan pada saat dana diterima oleh mudharib. Pencairan dana dilakukan setelah akad pembiayaan mudharabah disepakati oleh kedua pihak yaitu BMT dengan mudharib. BMT Manarul Qur'an Lumajang tidak memberikan layanan pembiayaan dalam bentuk aset nonkas. 


\section{Pengakuan Kerugian}

\section{Tidak Ada Jurnal}

BMT Manarul Qur'an Lumajang belum melakukan pencatatan kerugian akibat penurunan nilai investasi mudharabah akibat rusak, hilang atau faktor lain yang bukan dari kelalaian mudharib baik sebelum usaha dimulai atau setelah usaha dimulai karena BMT tidak memberikan layanan pembiayaan dalam bentuk aset non kas, serta belum mengakui kerugian yang terjadi dalam suatu periode sebelum akad mudharabah berakhir yaitu dengan tidak dibentuknya penyisihan kerugian investasi. Sehingga apabila ada kerugian dalam usaha yang dijalankan oleh pengelola dana (mudharib), kerugian tersebut mengurangi pendapatan bagi hasil bagi BMT dan pengelola dana.

\section{Pengakuan Keuntungan}

Tabel 2.

Pengakuan Keuntungan

\begin{tabular}{clcc}
\hline Tanggal & \multicolumn{1}{c}{ Jenis Data } & \multicolumn{2}{c}{ Dana } \\
\hline \multirow{2}{*}{$03-12-2018$} & Kas & Rp. 2.487.500 & \\
\cline { 2 - 3 } & Pendapatan Bagi Hasil-Umar & Rp. 2.487.500 \\
\hline
\end{tabular}
Sumber : BMT Manarul Qur'an Lumajang yang diolah

BMT Manarul Qur'an Lumajang mengakui keuntungan bagi hasil ketika mudharib menyetorkan pembayaran bagi hasil berdasarkan prosentase nisbah yang disepakati oleh kedua belah pihak di awal akad yang diperoleh dari pendapatan bersih usaha yang dijalankan pengelola dana (mudharib). Pembayaran bagi hasil dilakukan setiap bulan atau sesuai dengan kesepakatan kedua belah pihak.

\section{Pengakuan Piutang}

\section{Tidak Ada Jurnal}

BMT Manarul Qur'an Lumajang belum melakukan pencatatan piutang ketika pembiayaan mudharabah berakhir sebelum atau saat akad jatuh tempo dan bagi hasil yang belum dibayarkan oleh mudharib. BMT hanya mencatat ketika penerimaan kas dari mudharib. Pengembalian dana mudharabah di BMT Manarul Qur'an Lumajang dilakukan secara total diakhir akad. 
Tabel 3.

Pengakuan Piutang

\begin{tabular}{clcc}
\hline Tanggal & \multicolumn{1}{c}{ Jenis Data } & \multicolumn{2}{c}{ Dana } \\
\hline \multirow{2}{*}{$03-06-2018$} & Kas & Rp.10.000.000 & \\
\cline { 2 - 4 } & Pembiayaan Mudharabah-Umar & Rp. 2.487.500 & \\
\hline \multirow{2}{*}{$03-12-2018$} & Kas & Rendapatan Bagi Hasil-Umar & Rp. 487.500 \\
\cline { 2 - 3 } &
\end{tabular}

Sumber : BMT Manarul Qur'an Lumajang yang diolah

\section{Pengakuan Beban}

\section{Tidak Ada Jurnal}

Kerugian yang terjadi akibat kesalahan atau kelalaian mudharib akibat persyaratan yang telah ditentukan tidak terpenuhi, dibebankan kepada BMT dan mudharib dengan mengurangi pendapatan bagi hasil yang diperoleh.

Perlakuan Akuntansi Mengenai Pengukuran Pembiayaan Mudharabah di BMT Manarul Qur'an Lumajang

Tabel 4.

Pengakuan Pembiayaan Mudharabah

\begin{tabular}{clcc}
\hline Tanggal & \multicolumn{1}{c}{ Jenis Data } & Dana \\
\hline \multirow{2}{*}{$03-06-2018$} & Pembiayaan Mudharabah-Umar & Rp.10.000.000 & \\
\cline { 2 - 4 } & Kas & & Rp.10.000.000 \\
\hline
\end{tabular}

Pengukuran pembiayaan mudharabah pada BMT Manarul Qur'an Lumajang adalah diukur sebesar jumlah pembiayaan yang diserahkan kepada mudharib. BMT Manarul Qur'an Lumajang hanya memberikan pembiayaan mudharabah dalam bentuk kas dan tidak memberikan pembiayaan dalam bentuk aset nonkas.

Perlakuan Akuntansi Mengenai Penyajian Pembiayaan Mudharabah di BMT Manarul Qur'an Lumajang Berdasarkan PSAK No. 105

Tabel 5.

Penyajian Pembiayaan Mudharabah

\begin{tabular}{ll}
\hline \multicolumn{1}{c}{ ASET } & Dana \\
\hline Aset Lancar & Rp. 99.906 .000 \\
Kas & \\
Tabungan/Simpanan pada Bank: & Rp. 224.151.000 \\
Bank Syariah Mandiri & Rp. 200.199 .000 \\
BNI Syariah & \\
Pembiayaan: & \\
Pembiayaaan Murabahah & Rp. 58.580 .000 \\
Pembiayaan Mudharabah & Rp. 81.200 .000 \\
\hline
\end{tabular}




\begin{tabular}{ll}
\hline \multicolumn{1}{c}{ PENDAPATAN } & \\
\hline Pendapatan dari Penyaluran Dana: & \\
Pendapatan Margin Murabahah & Rp. 72.425 .000 \\
Pendapatan Bagi Hasil Mudharabah & Rp. 90.652 .000 \\
\hline
\end{tabular}

Pembiayaan mudharabah yang disalurkan BMT Manarul Qur'an Lumajang disajikan dalam neraca sebesar nilai yang tercatat, dan untuk bagi hasil usaha yang didapat disajikan dalam laporan hasil usaha atau setara dengan laporan laba rugi.

\section{Perlakuan Akuntansi Mengenai Pengungkapan Pembiayaan Mudharabah di BMT Manarul Qur'an Lumajang}

BMT Manarul Qur'an Lumajang mengungkapkan terkait isi kesepakatan usaha mudharabah dalam kontrak akad usaha, meliputi identitas pemohon, nominal peminjaman, jaminan yang diberikan, lama angsuran, jenis usaha, perjanjian bagi hasil dan tanda tangan dari pemohon dan karyawan BMT. BMT juga mengungkapkan jumlah pembiayaan mudharabah pada neraca serta pendapatan yang didapat pada hasil usaha.

\section{PEMBAHASAN}

Secara umum mudharabah adalah kerjasama antara dua atau lebih dari pihak pemilik modal (shahibul maal), yang mempercayakan sejumlah modal dengan kontribusi seratus persen (100\%) modal dari pemilik modal kepada pengelola (mudharib) (Muljono, 2015).

Berdasarkan hasil penelitian, ditemukan bahwa BMT Manarul Qur'an Lumajang belum sepenuhnya menerapkan PSAK No. 105 pada sistem akuntansi lembaga. Hasil yang serupa juga ditemukan di lembaga keuangan syariah lainnya seperti Bank BNI Syariah Kantor Cabang Mikro Kota Pareparep (Darmawan \& Hamid, 2018), BMT Gunungjati Cabang Kedawung Cirebon (Permata \& Wartoyo, 2017).

Berikut merupakan analisis kesesuaian sistem akuntansi BMT Manarul Qur'an Lumajang dengan PSAK No. 105:

\section{Analisis Kesesuaian Pengakuan Mengenai Pembiayaan Mudharabah}

\section{Pengakuan Investasi}

BMT Manarul Qur'an Lumajang memberikan pendanaan mudharabah berupa kas sebesar Rp. 10.000.000 yang disalurkan kepada Bpk. Umar diakui sebagai pembiayaan mudharabah. Namun berdasarkan data pada tabel 1, maka perlakuan 
akuntansi pada saat penyerahan dana yang dilakukan BMT Manarul Qur'an Lumajang belum sesuai dengan PSAK No. 105 paragraf 12, sebagaimana yang tercantum dalam PSAK No. 105 paragraf 12 menyebutkan dana mudharabah yang disalurkan oleh pemilik dana diakui sebagai investasi mudharabah pada saat pembayaran kas atau penyerahan aset nonkas kepada pengelola dana. Seharusnya pihak BMT Manarul Qur'an Lumajang menerapkan pencatatan sebagai berikut:

Tabel 6.

Pengakuan Investasi

\begin{tabular}{clc}
\hline Tanggal & \multicolumn{1}{c}{ Jenis Data } & \multicolumn{2}{c}{ Dana } \\
\hline \multirow{2}{*}{$03-06-2018$} & Investasi Mudharabah-Umar & Rp.10.000.000 \\
\cline { 2 - 3 } & Kas & Rp.10.000.000 \\
\hline
\end{tabular}

Selanjutnya pada PSAK No. 105 paragraf 16 menyebutkan bahwa usaha mudharabah dianggap mulai berjalan sejak dana atau modal usaha diterima oleh pengelola dana. Jika ditinjau dari perlakuan akuntansi pada BMT Manarul Qur'an Lumajang usaha mudharabah mulai berjalan ketika saat pencairan dana mudharabah kepada pengelola dana. Hal ini sudah sesuai dengan PSAK No. 105 paragraf 16.

\section{Pengakuan Kerugian}

BMT Manarul Qur'an Lumajang belum melakukan pencatatan kerugian akibat penurunan nilai investasi mudharabah akibat rusak, hilang atau faktor lain yang bukan dari kelalaian mudharib baik sebelum usaha dimulai atau setelah usaha dimulai karena tidak memberikan pelayanan aset non kas, serta tidak dibentuknya penyisihan kerugian investasi karena kerugian yang terjadi dalam suatu periode sebelum akad mudharabah berakhir. Kerugian dalam usaha yang dijalankan mudharib, ditanggung bersama oleh BMT dan mudharib, yaitu apabila ada kerugian mengurangi bagi hasil yang diterima oleh kedua belah pihak.

Berdasarkan PSAK No. 105 paragraf 10, jika dari pengelolaan dana mudharabah menimbulkan kerugian, maka kerugian finansial menjadi tanggungan pemilik dana. Kemudian PSAK No. 105 paragraf 21, kerugian yang terjadi dalam suatu periode sebelum akad mudharabah berakhir diakui sebagai kerugian dan dibentuk penyisihan kerugian investasi. Pada saat akad mudharabah berakhir, selisih antara :

Pengakuan kerugian dapat dilakukan dengan 2 cara yaitu sebagai berikut: 


\section{Langsung}

Tabel 7.

Pengakuan Kerugian Secara Langsung

\begin{tabular}{lcc}
\hline \multicolumn{1}{c}{ Rekening } & Debit (Rp) & Kredit (Rp) \\
\hline Db. Kerugian Investasi Mudharabah & $\mathrm{Xxx}$ & \\
\hline Kr. Investasi Mudharabah & & $\mathrm{Xxx}$ \\
\hline
\end{tabular}

\section{Tidak Langsung}

Tabel 8.

Pengakuan Kerugian Secara Tidak Langsung

\begin{tabular}{lcc}
\hline \multicolumn{1}{c}{ Rekening } & Debit (Rp) & Kredit (Rp) \\
\hline Db. Kerugian Investasi Mudharabah & Xxx & \\
\hline Kr. Penyisihan Kerugian Investasi Mudharabah & & Xxx \\
\hline
\end{tabular}

\section{Pengakuan Keuntungan}

BMT Manarul Qur'an Lumajang dalam menentukan pembagian hasil usaha sesuai dengan persentase nisbah bagi hasil yang disepakati oleh BMT dengan pengelola dana. Bagi hasil didapatkan dari pendapatan bersih usaha yang dikelola pengelola dana yaitu Bpk. Umar memperoleh keuntungan bersih sebesar Rp. 4.975.000, dan nisbah bagi hasil yang disepakati adalah 50:50, maka Bpk. Umar dan BMT memperoleh keuntungan sebesar Rp. 2.487.500.

BMT Manarul Qur'an Lumajang mengakui keuntungan bagi hasil ketika mudharib menyetorkan pembayaran bagi hasil berdasarkan prosentase nisbah yang sudah disepakati oleh kedua belah pihak yang diperoleh dari pendapatan bersih usaha yang dijalankan pengelola dana (mudharib). Pembayaran bagi hasil dilakukan setiap bulan atau sesuai dengan kesepakatan. Berdasarkan PSAK No. 105 paragraf 20 dan 22 dijelaskan bahwa: 1) paragraf 20, jika investasi mudharabah melebihi satu periode pelaporan, penghasilan usaha diakui dalam periode terjadinya hak bagi hasil sesuai nisbah yang disepakati; 2) paragraf 22, pengakuan penghasilan usaha mudharabah dalam praktik dapat diketahui berdasarkan laporan bagi hasil atas realisasi penghasilan usaha dari pengelola dana. Tidak diperkenankan mengakui pendapatan dari proyeksi hasil usaha. Dilihat dari pengakuan keuntungan bagi hasil pembiayaan mudharabah di BMT Manarul Qur'an sesuai dengan PSAK No.105 paragraf 20 dan 22. 


\section{Pengakuan Piutang}

BMT Manarul Qur'an Lumajang belum melakukan pencatatan piutang ketika pembiayaan mudharabah berakhir sebelum atau saat akad jatuh tempo dan bagi hasil usaha yang belum dibayarkan oleh mudharib, dalam pengembalian dana mudharabah pada BMT dilakukan secara total diakhir akad dan untuk bagi hasil dilakukan setiap bulan atau sesuai dengan kesepakatan. BMT selama ini melakukan pencatatan cash basic yaitu mencatat ketika penerimaan kas dari mudharib.

PSAK No. 105 paragraf 19 menjelaskan bahwa jika akad mudharabah berakhir sebelum atau saat akad jatuh tempo dan belum dibayar oleh pengelola dana, maka investasi tersebut diakui sebagai piutang.

Tabel 8.

Pengakuan Piutang (Investasi)

\begin{tabular}{lcc}
\hline \multicolumn{1}{c}{ Rekening } & Debit (Rp) & Kredit (Rp) \\
\hline Db. Piutang Investasi Mudharabah & Xxx & \\
\hline Kr. Investasi Mudharabah & & Xxx \\
\hline
\end{tabular}

PSAK No. 105 paragraf 24 menjelaskan, pembagian hasil usaha yang belum dibayar oleh pengelola dana diakui sebagai piutang.

Tabel 9.

Pengakuan Piutang (Bagi Hasil)

\begin{tabular}{lcc}
\hline \multicolumn{1}{c}{ Rekening } & Debit (Rp) & Kredit (Rp) \\
\hline Db. Piutang Pendapatan Bagi Hasil & Xxx & \\
\hline Kr. Pendapatan Bagi Hasil & & Xxx \\
\hline
\end{tabular}

\section{Pengakuan Beban}

BMT Manarul Qur'an Lumajang belum mencatat kerugian yang terjadi akibat kesalahan atau kelalaian pengelola dana (mudharib) akibat persyaratan yang telah ditentukan tidak terpenuhi, karena kerugian tersebut dibebankan kepada BMT dan mudharib dengan mengurangi bagi hasil dari pendapatan hasil usaha yang diperoleh.

Berdasarkan PSAK No. 105 paragraf 10 dan 23, dijelaskan bahwa: 1) paragraf 10, jika dari pengelolaan dana mudharabah menimbulkan kerugian, maka kerugian finansial menjadi tanggungan pemilik; 2) paragraf 23, kerugian akibat kelalaian atau kesalahan pengelola dana dibebankan pengelola dana dan tidak mengurangi investasi mudharabah. Dilihat dari pengakuan beban pembiayaan mudharabah di BMT Manarul Qur'an belum sesuai dengan PSAK No.105 paragraf 10 dan 23. 


\section{Analisis Kesesuaian Pengukuran Mengenai Pembiayaan Mudharabah}

Pembiayaan mudharabah di BMT Manarul Qur'an Lumajang diukur sebesar nilai atau jumlah dana yang diserahkan kepada mudharib. Hal ini telah sesuai dengan PSAK No. 105 paragraf 13 pada poin pertama yaitu investasi mudharabah dalam bentuk kas diukur sebesar jumlah yang dibayarkan.

\section{Analisis Kesesuaian Penyajian Mengenai Pembiayaan Mudharabah}

BMT Manarul Qur'an Lumajang dalam memberikan pembiayaan mudharabah tercatat dalam neraca sesuai besar pembiayaan mudharabah yang dilakukan. Selain itu bagi hasil yang dibayarkan oleh mudharib disajikan sebagai pendapatan bagi hasil sebesar jumlah yang diterima. Dalam hal ini telah sesuai dengan PSAK No. 105 paragraf 36 yang menyatakan bahwa pemilik dana menyajikan investasi mudharabah dalam laporan keuangan sebesar nilai tercatat.

\section{Analisis Kesesuaian Pengungkapan Mengenai Pembiayaan Mudharabah}

BMT Manarul Qur'an Lumajang mengungkapkan terkait isi kesepakatan usaha mudharabah dalam kontrak akad usaha, meliputi identitas pemohon, nominal peminjaman, jaminan yang diberikan, lama angsuran, jenis usaha, perjanjian bagi hasil dan tanda tangan dari pemohon dan karyawan BMT. BMT juga mengungkapkan jumlah pembiayaan mudharabah pada neraca, serta pendapatan yang didapat pada hasil usaha.

PSAK No. 105 paragraf 38 menjelaskan bahwa pemilik dana mengungkapkan hal-hal terkait transaksi mudharabah tetapi tidak terbatas pada: a) isi kesepakatan utama usaha mudharabah, seperti porsi dana, pembagian hasil usaha, aktivitas usaha mudharabah dan lain-lain; b) rincian jumlah investasi mudharabah berdasarkan jenisnya; c) penyisihan kerugian investasi mudharabah selama periode berjalan; d) pengungkapan yang diperlukan sesuai PSAK No. 101 tentang penyajian laporan keuangan syariah. Dilihat dari pengungkapan akuntansi mudharabah di BMT Manarul Qur'an sesuai dengan PSAK No.105 paragraf 38. 


\section{SIMPULAN}

Analisis penerapan akuntansi pembiayaan mudharabah di BMT Manarul Qur'an Lumajang pada pengakuan atas dana mudharabah belum sesuai dengan PSAK No. 105 dikarenakan BMT mengakuinya sebagai pembiayaan mudharabah, sedangkan menurut PSAK No.105 dana mudharabah yang disalurkan pada saat penyerahan kas atau aset non kas kepada nasabah diakui sebagai investasi mudharabah. Kerugian dan beban yang terjadi dalam usaha dibebankan kepada kedua belah pihak dengan mengurangi bagi hasil. Hal ini belum sesuai dengan PSAK No. 105. Saat pengakuan pembagian hasil usaha mudharabah di BMT Manarul Qur'an Lumajang sudah sesuai dengan PSAK No. 105. Selanjutnya pada pengukurannya BMT telah sesuai penerapannya dengan PSAK No. 105 yaitu pengukurannya sesuai dengan nominal yang diberikan kepada mudharib. Penyajian investasi mudharabah belum sesuai dengan PSAK No. 105 dikarenakan investasi dicatat sebagai pembiayaan pada neraca dan untuk pengungkapan telah sesuai dengan PSAK No. 105.

\section{DAFTAR PUSTAKA}

Ascarya, A. (2007). Akad dan Produk Bank Syariah. Bandung: PT Raja Grafindo Persada

Darmawan, D., \& Hamid, A. (2018). Penerapan Akuntansi Pembiayaan Mudharabah Berdasarkan PSAK No. 105 pada Bank BNI Syariah Kantor Cabang Mikro Kota Parepare. Jurnal Syari'ah dan Hukum Diktum, 16(1), 65-80

Dewan Syariah Nasional. (2000). Fatwa Dewan Syariah Nasional No. O7/DSNMUI/IV/2000 tentang Pembiayaan Mudharabah. http://mui.or.id/wpcontent/uploads/files/fatwa/07-Mudharabah.pdf

Laksmana, Y. (2009). Panduan Praktis Account Officer Bank Syariah. Jakarta: PT Elex Media Komputindo

Mardani, M. (2015). Aspek Hukum Lembaga Keuangan Syariah di Indonesia, Edisi Pertama. Jakarta: Kencana

Muljono, D. (2015). Perbankan dan Lembaga Keuangan Syariah, Edisi 1. Yogyakarta: ANDI

Otoritas Jasa Keuangan (OJK). (2018). Statistik IKNB Syariah. https://ojk.go.id/id/kanal/iknb/data-dan-statistik/statistikiknb/Default.aspx.

Otoritas Jasa Keuangan (OJK). (2018). Statistik Perbankan Syariah. https://ojk.go.id/id/kanal/syariah/data-dan-statistik/statistikperbankansyariah/Default.aspx. 
Permata, F. E., \& Wartoyo, W. (2017). Analisis Penerapan PSAK No. 105 pada Tabungan Berjangka Mudharabah dan Pembiayaan Mudharabah. Al-Amwal, 9(1), 145-161

Purwoko, S., \& Setiawan, N. (2016), Analisis Penerapan Akuntansi Pembiayaan Mudharabah Berdasarkan PSAK 105. Jurnal Profita: Kajian Ilmu Akuntansi, 5 (1), 1-14

Sugiyono, S. (2005). Metode Penelitian Bisnis. Bandung: CV.Alfa Beta

Yaya, R., \& Martawireja, A. E. (2012). Akuntansi Perbankan Syariah Teori dan Praktik Kontemporer. Jakarta: Salemba Empat 